has been contributed, mainly from their publications, by the museums of London and of the United States of America. It serves to bring out with considerable clarity the very different approach by the museums of the two countries to the problem of education. In London, largely owing to the manner in which the great national collections originated, and the way in which they have been built up, emphasis is laid on the function of the museum as a store-house of research and advanced critical appreciation, as well as, of course, as a place of exhibition of such part of the national wealth as is embodied in objects of artistic or historical interest and value concentrated in London. In the United States, on the other hand, the museums rely almost entirely upon funds from unofficial sources, whether from endowment or in the form of current income. In consequence, the latter have consistently stressed their educational function, directing it, naturally, in the first instance to the satisfaction of the interests or needs of their more immediate clientele.

Thrs difference is to be noted in the character of the posters advertising the national collections of Great Britain exhibited by the London Transport Board, and those shown here by the United States Museums, which consist of carefully devised and prepared propaganda material. The same difference is to be noted in the character of the two sets of publications. Whereas the English museums have prepared series of postcards and guides which offer a wealth of material bearing upon nearly every aspect of art, science and history, from which teachers are left to select for themselves, in the United States the museums, undertaking the direct educational function, circulate among the schools illustrative material selected by their own education departments, but rely mainly on the organized work and lectures of their own educational staffs, for which special accommodation is provided in the museum building.

\section{Human Problems of Management}

IN an address at the Commencement Exercises, Massachusetts Institute of Technology, on June 6, Sir Harold Hartley pointed out that, apart from new inventions and discoveries, the great changes in industry in this century have been largely in the direction of transforming traditional methods depending on the personal skill of the operator to scientifically controlled processes in which measurement has largely taken the place of craftsmanship. A new standard of certainty based on scientific measurement has invaded every branch of industry and engineering. The human problems of management, however, are equally important and are much more difficult than the selection and working of inanimate material. Success or failure may depend on the wise choice of men, in which there is no figure of merit as guide. There are also the wider human problems of industry and the collective life of the factory; the emotional response of the individual, the human understanding of the supervisor may influence efficiency and output as much as scientific planning. These human problems of management, Sir Harold said, become increasingly important with the size of the concern, and the rapid growth of the great corporations constitutes a new factor in our social organization, so that any danger of their inability to utilize human effort to the best advantage is an urgent problem. When an organization becomes too large for personal leadership, it is in danger of losing its character and vitality, of becoming mechanical, with all the loss of efficiency implied thereby in a human agency.

Organization, however, implies not only order in the distribution and co-ordination of the functions of the separate parts, but freedom for the individuals within their sphere of action. The remedy for the dangers of specialists through their ignorance outside their limited sphere of knowledge is a synthesis, which is the object of a large industrial undertaking in securing the co-operation of a team of specialists. Its smooth running depends on the ability of each of its component groups to engage intelligently in its particular task in proper co-ordination with the rest. Sir Harold Hartley does not believe that individual initiative disappears with increasing size. Without initiative there cannot be the steady flow of ideas, not merely outwards from the centre but inwards from each section, which is essential for success. The key problem is that of supplying adequate motive power in place of the self-interest motive, which must largely disappear. Accordingly, he stressed the importance of the study of incentives based on personal satisfaction, the development of the team spirit, and of the value of recognition in sweeping away negative inhibitions which hinder the possibility of achievement. It is the business of a leader to find the opportunities for success and to see that everyone is made to feel his part in them and to know that his part is recognized.

\section{Pre-Roman Archæology in Shropshire}

IN view of recent developments in the study of British archæology and prehistory in the period preceding the Roman invasion, considerable interest is attached to the announcement that the earthworks which crown the slopes of the Wrekin in Shropshire are to be excavated by the Society of Antiquaries of London in co-operation with the Shropshire Archæological Society. It is thought probable that the Wrekin was the headquarters of the tribe of the Cornovii before they were removed by the Romans to the riverside site of Viroconium or Uriconium, the modern Wroxeter, some time about A.D. 60-70, much as the tribesmen were removed from Maiden Castle to Dorchester in the same period. Uriconium itself, the Roman site, has recently boen excavated by Miss Kathleen Kenyon, and it is now the opinion of archæologists that the time has come to investigate the earlier site. It will be a matter of interest to see whether the suggestion thrown out by Dr. R. E. Mortimer Wheeler of an indication in his recent excavations in southern Brittany pointing in the direction of Shropshire is in any way borne out by the results of the investigation now contemplated. 